DROGUETT, Juan Guillermo; POMPEU, Bruno. Dicionário técnico e crítico da comunicação publicitária: conceitos fundamentais. São Paulo: Cia dos Livros, 2012: 125.

\title{
PALAVRAS EM AÇÃO
}

\section{João Anzanello Carrascoza ${ }^{1}$}

Um episódio medieval, dos tempos em que Cervantes ainda sonhava com seu Quixote, conta que dois meninos se conheceram enquanto seus pais colhiam azeitonas. Filhos de pobres camponeses, no entanto, desafiavam um ao outro, inventando proezas cada vez mais hiperbólicas realizadas por seus familiares. Até que um deles vence a contenda, afirmando que o tio, um nobre e rico senhor, possuía tantas terras que o céu, apesar de imenso, não era grande o bastante para cobri-las inteiramente.

Este desfecho espirituoso, que poderia figurar numa das próprias páginas protagonizadas pelo cavaleiro da triste figura, me vem à memória a propósito da publicação do Dicionário técnico e crítico da comunicação publicitária, de Juan Guillermo D. Droguett e Bruno Pompeu.

Feito de inegável monta, que certamente exigiu vasta pesquisa e rigorosa conferência de informações, este dicionário, pioneiro no Brasil, surge para cobrir o território, em constante expansão, dos estudos relacionados à comunicação publicitária e a áreas interconexas, com as quais ela dialoga, se mescla e se imbrica, misturando suas águas.

Se falta à obra um o outro termo capital, ou descrito de forma menos exaustiva, seu resultado não constitui uma lona rústica, mas um esmerado tecido que, de fato, cumpre o objetivo de nos trazer conceitos fundamentais do universo publicitário, historiando-os com competência e detalhamentos. Temos, pois, um cobertor de verbetes, finamente tramado, com nós e laços bem urdidos, desvelando suas

\footnotetext{
${ }^{1}$ Doutor em Ciências da Comunicação pela Universidade de São Paulo, docente e pesquisador do Programa de Pós-Graduação em Comunicação e Práticas de Consumo da Escola Superior de Propaganda e Marketing (São Paulo). Endereço: Rua Doutor Álvaro Alvim, 123 Vila Mariana - São Paulo-SP. Tel.: (11) 5085-4687.
} 
correspondências e seus distanciamentos teóricos e práticos. Cada verbete não é somente registrado, mas desdobrado desde seu advento, atingindo a condição de estado da arte.

Além do amplo conjunto de termos dicionarizados, no qual é possível confirmar em cada página o compromisso crítico dos autores, é este justamente outro mérito da obra: os verbetes estão vivos. Diferentemente do poema de Carlos Drummond de Andrade, "A procura de poesia", as palavras não estão, aqui, em estado de dicionário - indiferentes e à espera de que o leitor traga a chave para lhes dar sentido.

Droguett e Pompeu apresentam os verbetes fora de seu costumeiro estado de solidez, garantindo-lhes a seiva do contexto e deixando-os abertos para novos e vindouros significados. Em suma: são verbetes ativos, e, assim sendo, haverão da dar vida aos debates clássicos e às questões emergentes sobre a publicidade em seu âmbito acadêmico e profissional.

Ao lado de termos técnicos, cotidianos nas agências de propaganda, como, por exemplo, all-type, brand, job, slogan, estão também, referenciadas e discutidas, as definições de cultura de massa, Escola de Frankfurt, consumo e modernidade/pós- modernidade, entre outras.

Não há dúvida que, tanto para os estudiosos e teóricos, quanto para aqueles que fazem da comunicação publicitária a sua práxis, esta obra há de ser de indiscutível valia: para gerar reflexão, consubstanciar tendências e, sobretudo, cobrir com seus conceitos basilares um pouco mais os extensos campos do fenômeno publicitário na contemporaneidade.

Artigo submetido: dezembro de 2012

Artigo aprovado: dezembro de 2012 